\title{
Effects of hydrographic and climatic forcing on diatom production and export in the tropical southeastern Indian Ocean
}

\author{
Oscar E. Romero ${ }^{1, *}$, Tim Rixen ${ }^{2}$, Bambang Herunadi ${ }^{3}$ \\ ${ }^{1}$ Instituto Andaluz de Ciencias de la Tierra (IACT-CSIC), Campus Fuentenueva, Facultad de Ciencias, \\ Universidad de Granada, 18002 Granada, Spain \\ ${ }^{2}$ Center for Tropical Marine Ecology, Fahrenheitstr. 6, 28359 Bremen, Germany \\ ${ }^{3}$ The Agency for Marine and Fisheries Research, Jl. Pasir Putih I, Ancol Timur, 12779 Jakarta-Utara, Indonesia
}

\begin{abstract}
We examined a 32 mo continuous record of the flux of diatoms, silicoflagellates and bulk components collected between November 2000 and July 2003 at the pelagic mooring site Java Mooring (JAM), off southern Java in the tropical southeastern Indian Ocean. Temporal variations in the flux mainly reflected the dynamics of monsoon-driven seasonality of oceanographic and atmospheric conditions. Highest diatom fluxes coincided with the SE monsoon season during La Niña in September 2001, with the NW monsoon season in February/March 2003 and with the early SE monsoon season in 2003. Enhanced fluxes of diatoms, opal and organic carbon toward the end of the NW monsoon season are related to riverine nutrient inputs and the subsequent development of diatom-dominated phytoplankton blooms. During the SE monsoon season, the entrainment of nutrients from the subsurface into surface waters, due to upwelling, enhanced flux. A highly diverse diatom community characterized the fluxes throughout the sampling period. Several pelagic, warm-water species of the genus Nitzschia, accompanied by Thalassionema nitzschioides var. parva and T. nitzschioides var. inflata, dominated during periods of strong stratification, high sea surface temperature and low surface water productivity. The simultaneous occurrence of the pelagic Azpeitia tabularis, Fragilariopsis doliolus and Planktoniella sol and the coastal planktonic diatoms Actinocyclus curvatulus and Thalassiosira oestrupii var. venrickae reveals the intermingling of water masses of moderate-to-low nutrient content. Coastal upwelling diatoms Thalassionema nitzschioides var. nitzschioides and resting spores of Chaetoceros spp. occur most abundantly during the NW monsoon season. The diatom assemblage at the JAM site responded, with slight changes, to El Niño/Southern Oscillation occurrence. The co-occurrence of diatom species with different ecological affinities mirrors the fact that the JAM site was located in a region with large hydrographic variability over short time intervals.
\end{abstract}

KEY WORDS: Diatoms · Particle fluxes · Monsoon · Upwelling · Indian Ocean · Indonesian Archipelago

\section{INTRODUCTION}

The SE Indian Ocean off southern Java is a key area along the return branch of the global conveyor belt (Gordon 2005). It is well known that small changes in the sea surface temperature (SST) in this area can result in significant changes of precipitation patterns across the Indo-Pacific region (Neale \& Slingo 2003), the thermocline structure in the southern Atlantic (Hirst \& Godfrey 1993) and the global heat exchange (Gordon et al. 1992). The variability pattern in surface primary productivity, chlorophyll a concentration, SST, water mass circulation and the position of the Intertropical Convergence Zone (ITCZ) in the SE 
Indian Ocean are strongly monsoonal (Gordon 2005, Qu et al. 2005, Susanto et al. 2006).

The island of Java has a unique position in the western Indonesian Archipelago and experiences a strong response to monsoon seasonality. The seasonal swing of the SST is accentuated by Ekman upwelling: during the SE monsoon, southeasterly winds from Australia generate upwelling along the Java and Sumatra coasts (Gordon 2005). During the NW monsoon, NW winds produce weaker biological responses. Interannual variability in the upwelling intensity is present, probably as a consequence of annual variations in atmosphere-ocean teleconnections (Susanto et al. 2001). The intensity and seasonality of the monsoonal winds, and their complex interplay with climate phenomena such as the El Niño/Southern Oscillation (ENSO) and the Indian Ocean Dipole (IOD), may therefore be influenced by sea-air exchange processes and the inter-ocean throughflow within the Indonesian seas (Saji et al. 1999, Webster et al. 1999, Susanto et al. 2001).

Information on the temporal dynamics of diatom production is still scarce for the entire Indian Ocean. Based on net samples collected during the Indian Ocean Expedition of the RV 'Meteor', Simonsen (1974) took an inventory of all diatom species encountered within an extensive working area along the NE African coast, the Persian Gulf, the Gulf of Oman and the western coast of India, and included remarks on the distribution and ecology of these species. Koning et al. (2001) studied the diatom composition of settling particles collected in sediment traps off Somalia, NW Indian Ocean. In this area, diatoms represented $>90 \%$ of the total siliceous microorganisms. A distinct succession of seasonal diatom species of 'pre-upwellers', 'upwellers' and 'oceanic species' occurred off Somalia (Koning et al. 2001). Less is known, however, about the seasonal dynamics of diatom populations and the contribution of diatoms to primary production and opal fluxes in the tropical SE Indian Ocean.

Materials collected by sediment trap allow the characterization of the seasonal and interannual variability of bulk and microorganism fluxes. In particular, assessment of the temporal occurrence of planktonic organisms helps in the calibration of species-specific ecological tolerances, as well as in the species potential for paleoceanographic reconstructions in a particular study area. In the present study, we examined a 32 mo continuous record of bulk component, diatom and silicoflagellate fluxes collected at the pelagic JAM site deployed off southern Java at approximately $8^{\circ} 16^{\prime} \mathrm{S}, 108^{\circ} 09^{\prime} \mathrm{E}$ between November 2000 and July 2003. A central objective of our work was to determine the effect of seasonal and interannual variability of hydrography, winds and nutrient availability on the production and export of diatoms and silicoflagellates. We demonstrated that variations in the qualitative composition of the diatom community mainly follow monsoonal-driven changes in the oceanographic and climatic conditions of the western tropical Indian Ocean. Our observations on the present-day distribution of diatoms off southern Java will help in the interpretation of diatoms as indicators of past environmental changes: mainly those involving variations in upwelling intensity and productivity.

\section{Oceanographic setting}

The monsoonal circulation and the seasonal migration of the ITCZ drive the seasonal dynamics of its climate and hydrography off southern Java. During the austral summer (boreal winter), a southerly position of the ITCZ and the seasonal occurrence of the NW monsoon lead to an accumulation of large amounts of moisture gathered by crossing SE Asian and Indonesian seas and resulting in heavy rains in Sumatra and Java (Gordon 2005). During the austral winter (boreal summer), the SE monsoon originates in the high-pressure belt of the southern hemisphere and is relatively dry and cool when it reaches Indonesia (Gordon 2005). The $\mathrm{SE}$ monsoon gains moisture from the Indonesian and SE Asian seas and meets the ITCZ in a northerly position, leading to heavy precipitation on the SE Asian mainland. The SE winds also foster coastal upwelling south of Java, which is associated with lower SSTs and higher chlorophyll a concentrations (Gordon 2005, Susanto et al. 2006).

Ocean currents in the SE Indian Ocean move according to the wind regime. During the NW monsoon season, the South Java Current, derived from the Equatorial Counter Current (Fig. 1), moves towards the southeast to meet the Leeuwin Current, a narrow strip of warm, saline waters that originates in the eastern part of the Indonesian Archipelago (Tomczak \& Godfrey 1994). The South Java Current and the Leeuwin Current combine to form the South Equatorial Current, which moves westward at $\sim 15^{\circ} \mathrm{S}$ (Fig. 1). In the SE monsoon season, the South Java Current takes an opposite direction, flowing northwestward and feeding the South Equatorial Current, thus reducing its contribution to the Leeuwin Current. Advection of fresher Java Sea waters through the Sunda Strait and run-off from Sumatra and Java are responsible for the low-salinity 'tongue' in the South Java Current ( $Q u$ et al. 2005). The thick barrier layer off Sumatra that prevents cold thermocline water from entering the mixed layer explains why the SST depression off Sumatra is small compared to other eastern boundary upwelling areas (Qu et al. 2005). 


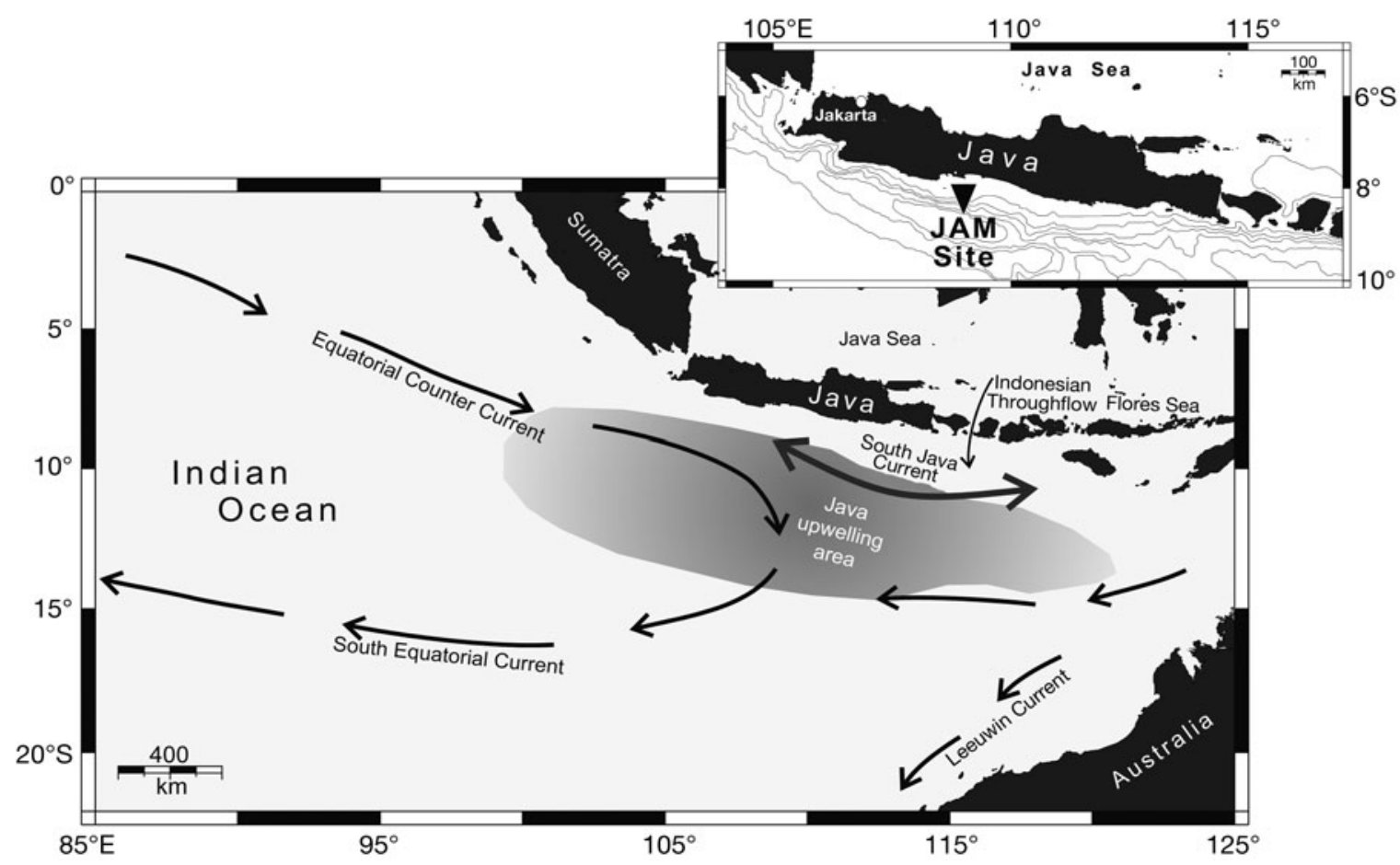

Fig. 1. Schematic map of the study area showing the principal surface currents (black arrows; after Gordon \& Fine 1996). The gray shading (darker shades indicate greater intensity) represents the upwelling area off Java and Sumatra. The insert depicts the location of the mooring site JAM off southern Java in the SE tropical Indian Ocean

The Indonesian Throughflow, the only present-day, low-latitude oceanic connection between the major ocean basins, enters the Indian Ocean as a response to the higher steric height in the Pacific Ocean (Gordon 2005). The Java upwelling system is counterbalanced by increases in the Indonesian Throughflow and, consequently, except for brief periods, fails to bring subsurface nutrients to the surface (Godfrey 1996). In addition, the Indonesian Throughflow flows through the Lombok Strait, also neutralizing a significant SST depression off Java during the upwelling season.

\section{MATERIALS AND METHODS}

JAM mooring site. A time-series sediment trap MARK VII was deployed at a water depth of approximately $2200 \mathrm{~m}$ at the JAM site $\left(08^{\circ} 16.4^{\prime} \mathrm{S}, 108^{\circ} 08.96^{\prime} \mathrm{E}\right.$; Fig. 1) between November 2000 and July 2003 (Rixen et al. 2006). During the sampling period, 55 samples were taken, with a time resolution varying between 12 and $22 \mathrm{~d}$. Details on sampling intervals and daily fluxes are presented in Table 1.

Chemical analyses of bulk biogenic particles. We followed the methods previously detailed in Rixen et al. (2006). Total carbon and organic carbon were determined using a Carlo Erba Nitrogen Analyzer 1500. Calcium carbonate results were derived from the dif- ference between total and organic carbon. Opal concentration was determined photometrically after extraction of silicon with a sodium carbonate solution (Mortlock \& Froelich 1989).

Siliceous phytoplankton analysis. For the present study either $1 / 16$ or $1 / 64$ splits of the original samples were used. Samples were rinsed with distilled water and prepared according to the methodology described by Romero et al. (1999, 2000). Diatom and silicoflagellate analyses were carried out on permanent slides of acid-cleaned material (Mountex mounting medium). Qualitative and quantitative analyses were done at 1000× magnification using a Zeiss-Axioscope with phase-contrast illumination. Several traverses across the slide were examined, depending on abundance (between 400 and 750 valves slide ${ }^{-1}$ were counted). Each diatom was identified to the lowest taxonomic level possible. Silicoflagellates were only identified at group level. Counting of 2 replicate slides indicated that the analytical error for the diatom and silicoflagellate flux estimates was $\leq 15 \%$. The resulting counts yielded the abundance of individual diatom taxa as well as daily fluxes of diatom valves and silicoflagellate skeletons $\mathrm{m}^{-2} \mathrm{~d}^{-1}$ calculated according to Sancetta \& Calvert (1988), as follows:

$$
F=\frac{(N) \times(A / a) \times(V) \times(\text { Split })}{(\text { days }) \times(D)}
$$


Table 1. Daily flux of total particles, opal, calcium carbonate, organic carbon, lithogenics, diatoms and silicoflagellates at the JAM mooring site $\left(29^{\circ} 12^{\prime} \mathrm{S}, 13^{\circ} 07^{\prime} \mathrm{E}\right)$ off southern Java in the tropical SE Indian Ocean from November 2001 to July 2003

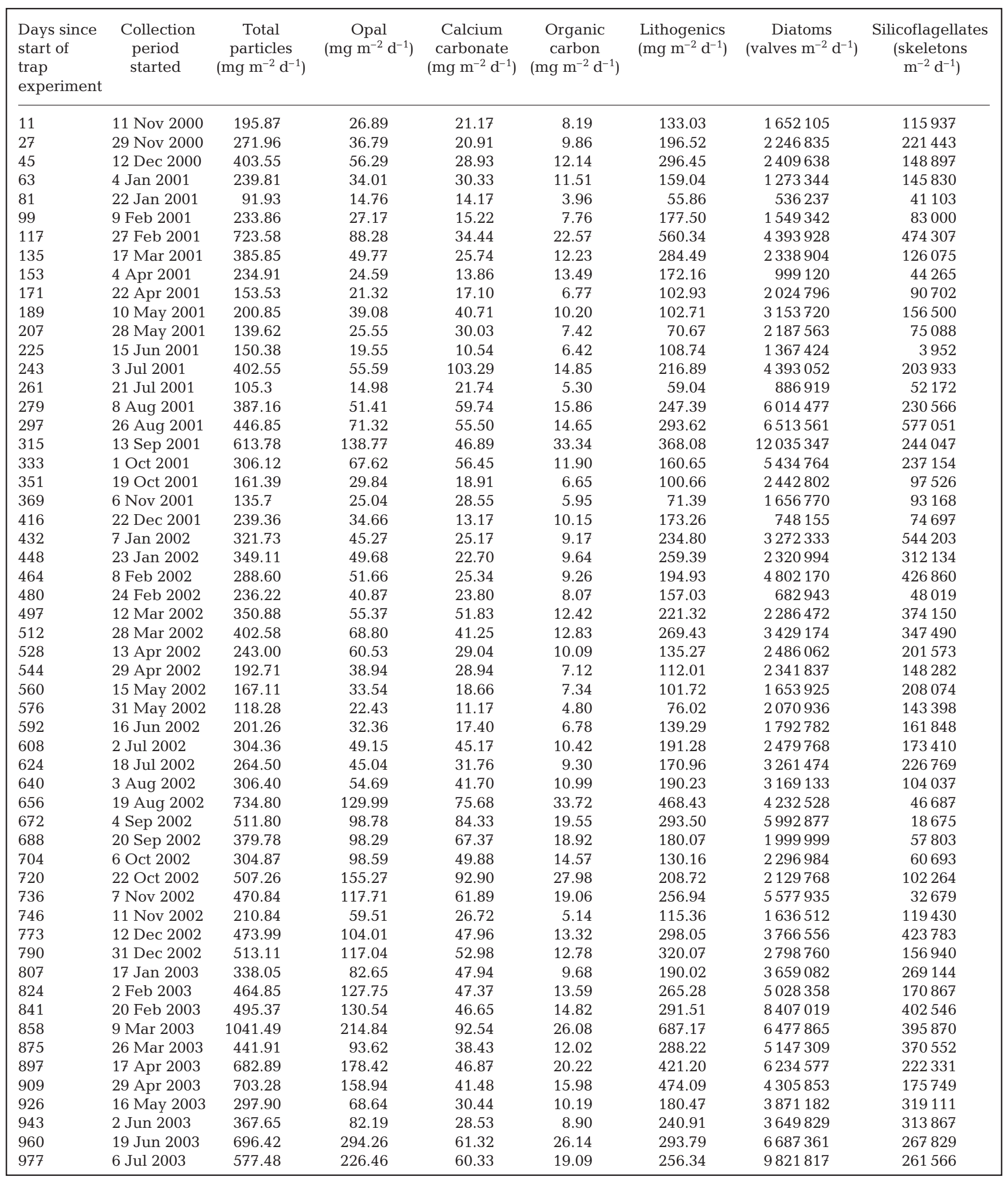


where $(N)$ is the number of specimens (valves), in an area (a), as a fraction of the total area of a Petri dish $(A)$ and the dilution volume $(V)$ in milliliters. This value is multiplied by the sample split (Split), representing the fraction of total material in the trap, and then divided by the number of days (days) of deployment and the trap collection area $(D)$.

Principal components analysis. To investigate thecovariability between the different diatom populations, as observed in a preliminary analysis of the temporal distribution of species, a principal component analysis (PCA) was carried out by means of SPSS, Version 15.0.1 (http://support.spss.com/Products Ext/SPSS/Patches/SPSSforWindows/). The extraction of principal components amounts to a variance maximizing (varimax) rotation of the original variable space. The criterion for the rotation is to maximize the variance (variability) of the 'new' variable (factor), while minimizing the variance around the new variable. Out of approximately 150 diatom species recognized in 55 sediment trap samples, the PCA covered the 22 most abundant diatom species. The average relative contribution of each of these 22 diatoms exceeds $1 \%$ for the entire sampling period. The diatom dataset from the JAM sediment trap results in 5 factors (diatom Groups 1 to 5) that account for ca. $76 \%$ of the original variance.

\section{RESULTS}

\section{Total particle flux}

Total particle flux peaked in every NW and SE monsoon season, except for the NW monsoon season in 2002 (Table 1, Fig. 2). Major peaks (>600 $\mathrm{mg} \mathrm{m}^{-2} \mathrm{~d}^{-1}$ ) occurred in early March 2001, September/October 2001, August/September 2002 and February/March 2003. The magnitude of maxima differed from year to year. Total particle flux was mainly composed of lithogenics, the contribution of which varied strongly on a seasonal basis (Fig. 2). Opal (biogenic silica) was the main component of the bulk biogenic flux. The highest opal maxima ( $>150 \mathrm{mg} \mathrm{m}^{-2} \mathrm{~d}^{-1}$ ) occurred in September/October 2001, August/September and October/November 2002, and February/March and June 2003. The flux of organic carbon was generally enhanced at the end of the NW and during the SE monsoon seasons. Calcium carbonate had 3 main maxima: 2 during SE monsoon seasons (2001 and 2002) and 1 during the 2003 NW monsoon season.

\section{Seasonal and interannual variations in diatom fluxes}

The diatom flux ranged from $5.4 \times 10^{5}$ to $1.2 \times$ $10^{7}$ valves $\mathrm{m}^{-2} \mathrm{~d}^{-1}$ between November 2000 and July 2003 (Table 1, Fig. 3). Highest diatom maxima (>8.4 $\times$ $10^{6}$ valves $\mathrm{m}^{-2} \mathrm{~d}^{-1}$ ) occurred mostly during the monsoon seasons in September 2001, February/March 2003 and June/July 2003. Secondary peaks in diatom flux $\left(4.4 \times 10^{6}\right.$ to $6.2 \times 10^{6}$ valves $\left.\mathrm{m}^{-2} \mathrm{~d}^{-1}\right)$ occurred in February/March 2001, early February 2002, early September 2002, early November 2002, February/March 2003 and late June 2003. Fluxes of silicoflagellates followed a similar temporal pattern to that exhibited by diatoms, except during the 2002 SE monsoon season (Table 1, Fig. 3).

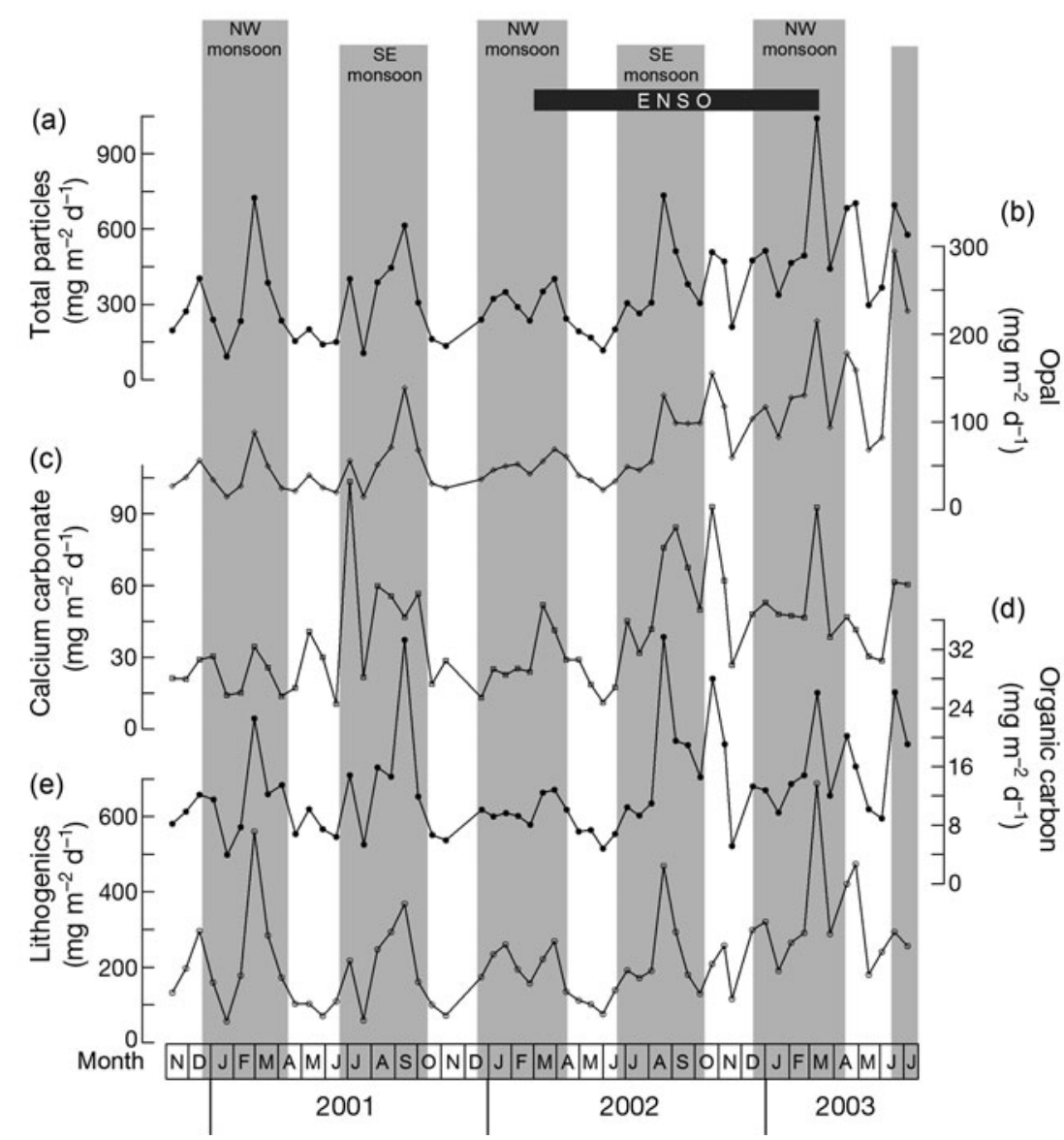

Fig. 2. Temporal changes in the flux of (a) total particles, (b) opal, (c) calcium carbonate, (d) organic carbon and (e) lithogenics $\left(\mathrm{mg} \mathrm{m}^{-2} \mathrm{~d}^{-1}\right)$ at the mooring site JAM off southern Java in the tropical SE Indian Ocean from November 2000 through to July 2003 (see also Table 1). Grey shading highlights the NW and SE upwelling seasons. ENSO: El Niño/Southern Oscillation 


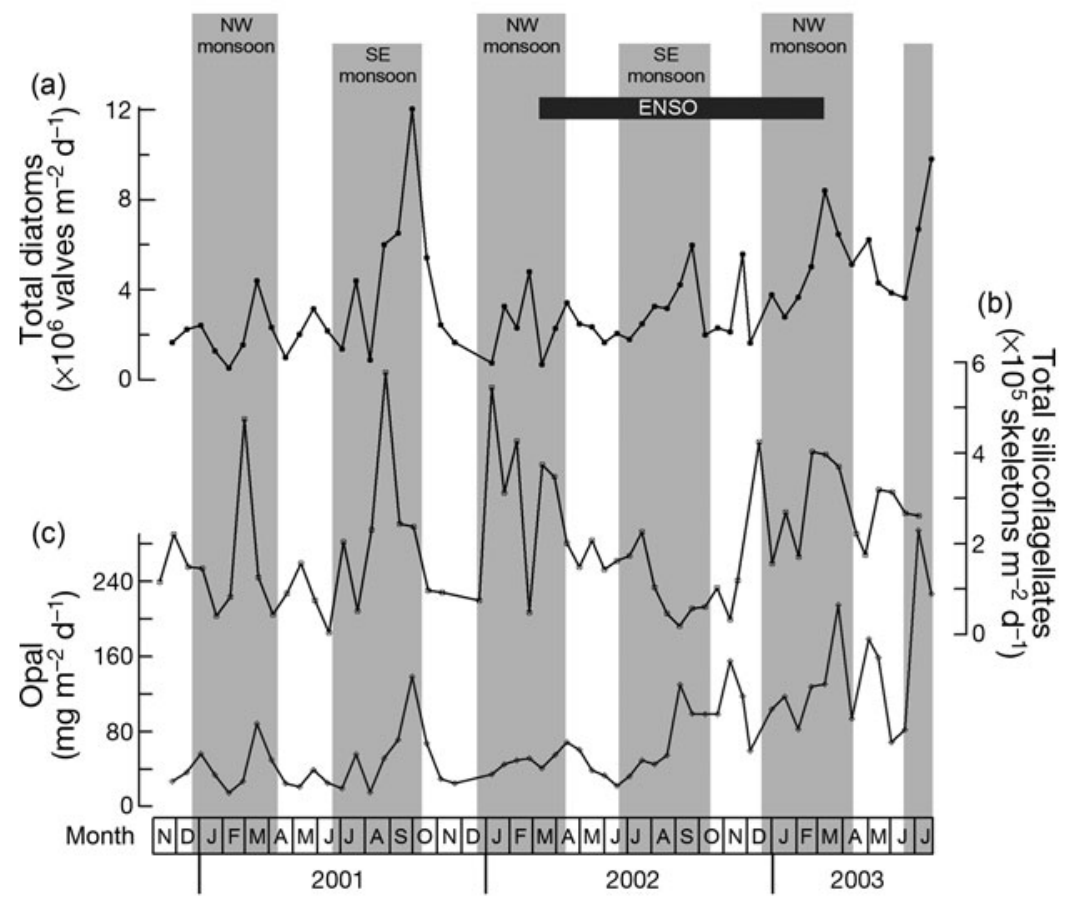

Fig. 3. Temporal changes in the flux of (a) total diatoms (valves $\mathrm{m}^{-2} \mathrm{~d}^{-1}$ ), (b) total silicoflagellates (skeletons $\mathrm{m}^{-2} \mathrm{~d}^{-1}$ ) and (c) opal $\left(\mathrm{mg} \mathrm{m}^{-2} \mathrm{~d}^{-1}\right.$ ) at the mooring site JAM off southern Java in the tropical SE Indian Ocean from November 2000 through July 2003 (see also Table 1). Grey shading highlights the NW and SE upwelling seasons. ENSO: El Niño/Southern Oscillation

ularis $(1.0 \%)$. Several neritic diatoms contributed seasonally to the flux: Thalassionema nitzschioides var. nitzschioides $(9.7 \%)$, resting spores of Chaetoceros spp. $(6.6 \%)$, Actinocyclus curvatulus $(5.9 \%)$, Thalassiosira oestrupii var. venrickae $(4.6 \%)$ and Cyclotella litoralis $(1.0 \%)$.

Due to the high diversity of the diatom assemblage at the JAM site and in order to summarize the ecological information delivered by the main diatom contributors, we applied PCA to the relative abundance ( $\%$ ) of 22 diatom species. The first 5 components explained $76 \%$ of the total variance (Tables 2 \& 3). Group 1 ( $\sim 31 \%$ of the total variance) comprised the oligotrophic, open-ocean, warmwater diatoms Nitzschia bicapitata, $N$. interruptestriata and $N$. sicula, with minor contributions by Thalassionema nitzschioides var. inflata and T. nitzschioides var. parva. The highest relative contribution of Group 1 occurred during May/July 2001 and May/July 2002 (Fig. 4). Group 2, which explained $\sim 17 \%$ of the variance, comprised Azpeitia tabularis, Fragilariopsis doliolus, Planktoniella sol, Rhizosolenia bergonii, Thalassionema frauenfeldii, Thalassiosira

\section{Temporal variations in the abundance of diatom species}

The opal fraction at the JAM site comprised 165 marine and 13 freshwater diatoms, silicoflagellates, radiolarians, phytoliths and the dinoflagellate Actiniscus pentasterias. The complete list of diatom species is given in Appendix 1. In terms of the numbers of individuals, diatoms dominated the opal fraction throughout the year: their flux was always 1 to 4 orders of magnitude higher than that of the other siliceous organisms encountered. Fig. 3 depicts the temporal variations in the fluxes of diatoms and silicoflagellates.

The most important contributors to the diatom flux were the pelagic species Nitzschia bicapitata (average relative contribution for the entire sampling period $=$ 15.0\%), Thalassionema nitzschioides var. parva $(8.5 \%), N$. interruptestriata $(4.4 \%)$, Thalassionema bacillare $(3.0 \%)$, Thalassiosira subtilis $(2.3 \%)$, Rhizosolenia bergonii (2.0\%), Planktoniella sol (1.9\%), Fragilariopsis doliolus (1.9\%), Thalassiosira oestrupii var. oestrupii $(1.3 \%)$, N. sicula $(1.2 \%)$, Thalassiosira lineata $(1.2 \%), \quad$ Thalassionema nitzschioides var. inflata (1.2\%), Rhizosolenia setigera (1.1\%) and Azpeitia tab- oestrupii var. oestrupii and Thalassiosira subtilis, pelagic species thriving in oligotrophic-to-mesotrophic waters of low-to-intermediate latitude oceans and the coastal Cyclotella litoralis. The relative contribution of Group 2 decreased steadily from the beginning of the sampling period until August/September 2002, peaked during October/November 2002 and decreased thereafter (Fig. 4). Group 3 comprised a mixture of coastal components, such as spores of an unidentified Chaetoceros species and Thalassionema nitzschioides var. nitzschioides, accompanied by pelagic Thalassionema bacillare and $R$. setigera, and explained $11.5 \%$ of the total variance. Group 3 peaked mainly during the NW monsoon season (Fig. 4). The coastal diatoms Actinocyclus curvatulus and Thalassiosira oestrupii var. venrickae were the main components of Group 4, with minor contributions from the pelagic Thalassiosira lineata. The temporal occurrence of Group 4 resembled that of Group 2. Group 5 mainly represents a coastal upwelling-related signal comprised of 2 resting spores of Chaetoceros spp. (C. affinis and C. compresus) ( $7.5 \%$ of the total variance). Group 5 showed maxima during the late SE monsoon season in 2001 and 2002, and in the early NW monsoon season in 2003. 
Table 2. Varimax loadings matrix (rotation: varimax normalized). Factor scores for analysis of 55 sediment trap samples using 22 diatom taxa with average abundances $\geq 1.0 \%$ of the total diatom assemblage at the JAM site between November 2000 and July 2003. Bold print indicates the dominant species or group of species within each factor (loadings $>0.700$ ). For the relative contribution of each factor (group) see Fig. 4. RS: resting spore

\begin{tabular}{|c|c|c|c|c|c|}
\hline Diatom species & Group 1 & Group 2 & Group 3 & Group 4 & Group 5 \\
\hline Actinocyclus curvatulus & 0.061 & 0.422 & -0.311 & 0.516 & -0.449 \\
\hline Azpeitia tabularis & 0.168 & 0.675 & 0.144 & 0.007 & 0.202 \\
\hline Chaetoceros affinis RS & -0.303 & 0.263 & -0.188 & -0.425 & 0.501 \\
\hline Chaetoceros compresus RS & 0.166 & -0.140 & -0.409 & 0.263 & 0.456 \\
\hline Chaetoceros sp. RS & -0.190 & 0.163 & 0.504 & -0.108 & 0.029 \\
\hline Cyclotella litoralis & 0.096 & 0.599 & 0.023 & -0.001 & 0.245 \\
\hline Fragilariopsis doliolus & 0.138 & 0.577 & -0.118 & 0.477 & 0.060 \\
\hline Nitzschia bicapitata & 0.376 & -0.584 & -0.580 & -0.064 & -0.066 \\
\hline Nitzschia interruptestriata & 0.614 & 0.483 & -0.0765 & 0.397 & -0.087 \\
\hline Nitzschia sicula & 0.516 & 0.132 & -0.206 & -0.164 & -0.125 \\
\hline Planktoniella sol & -0.083 & 0.502 & 0.134 & 0.163 & 0.253 \\
\hline Rhizosolenia bergonii & -0.654 & 0.477 & -0.143 & 0.164 & -0.160 \\
\hline Rhizosolenia setigera & 0.169 & -0.108 & 0.817 & -0.063 & -0.261 \\
\hline Thalassionema bacillare & -0.188 & -0.603 & 0.483 & -0.254 & 0.263 \\
\hline Thalassionema frauenfeldii & 0.166 & 0.535 & -0.465 & 0.260 & 0.252 \\
\hline Thalassionema nitzschioides var. nitzschioides & 0.086 & -0.237 & 0.674 & -0.094 & 0.385 \\
\hline Thalassionema nitzschioides var. inflata & 0.546 & 0.033 & 0.118 & 0.406 & -0.264 \\
\hline Thalassionema nitzschioides var. parva & 0.630 & 0.416 & -0.078 & 0.155 & 0.210 \\
\hline Thalassiosira lineata & -0.030 & -0.596 & -0.341 & 0.161 & 0.111 \\
\hline Thalassiosira oestrupii var. oestrupii & -0.598 & 0.340 & -0.080 & 0.273 & 0.066 \\
\hline Thalassiosira oestrupii var. venrickae & 0.065 & -0.363 & 0.081 & 0.533 & 0.314 \\
\hline Thalassiosira subtilis & 0.263 & 0.519 & 0.140 & -0.274 & -0.428 \\
\hline
\end{tabular}

\section{DISCUSSION}

Variations in the magnitude of fluxes at the JAM site mirrored the temporal variability of hydrographic and atmospheric conditions off southern Java in the SE tropical Indian Ocean. Good correlations between diatoms and organic carbon $(\mathrm{r}=0.68, \mathrm{n}=55)$ and diatoms and opal $(r=0.69, n=55)$ show that the seasonal cycle of diatom production and export was strongly coupled with the monsoon's seasonality. The dependence of diatom production on nutrient availability is clearly shown by the monsoon-driven seasonality of fluxes: almost $70 \%$ of the total annual diatom flux was intercepted during the NW and SE monsoon seasons at the JAM site (Fig. 5). Enhanced fluxes of diatoms, opal and organic carbon towards the end of the NW monsoon seasons were related to the riverine nutrient input and the subsequent development of a diatom-dominated phytoplankton bloom. During the SE monsoon season, the entrainment of nutrients from the subsurface into surface waters due to upwelling was found to enhance flux.

\section{SE monsoon}

The highest diatom, opal and organic carbon fluxes recorded between June and August reveal the greatest seasonal effect on the productivity of surface waters along the southern coast of Java in response to the SE monsoon upwelling season (Moore et al. 2003). The biweekly averaged flux rate of organic carbon and the siliceous fraction (opal, diatoms and silicoflagellates) shows double peaks, one at the beginning and one at the end of the upwelling SE monsoon season (Fig. 5). Maxima of bi-weekly averaged fluxes early in the SE monsoon upwelling season were probably due to the shallowing out of the mixed layer and the associated input of nutrients from subsurface waters as a consequence of the increasing wind stress (Qu et al. 2005). The second peak at the end of the SE monsoon season is related to the bloom of diatoms due to the occurrence of upwelling off southern Java.

During our trap experiment, the weak La Niña conditions turned into weak ENSO conditions in early 2002, as indicated by the Southern Oscillation Index falling from 2 to -1.5 (Fig. 4). It has been proposed that

Table 3. Total variance explained by the first 5 factors of the principal component analysis (see Table 2)

\begin{tabular}{|lcc|}
\hline Factor & Variance $(\%)$ & Accumulated variance \\
\hline 1 & 30.76 & 30.76 \\
2 & 17.34 & 48.10 \\
3 & 11.47 & 59.57 \\
4 & 8.93 & 68.50 \\
5 & 7.54 & 76.04 \\
\hline
\end{tabular}


ENSO suppresses the build up of the buoyant lowsalinity layer during the NW monsoon, due to its impact on precipitation rates over Indonesia (Rixen et al. 2006). Since this layer caps off the nutrient-enriched subsurface waters and has to be removed in order to allow nutrients to upwell, a thinner, low-salinity layer is responsible for the increase in the mean SE monsoon fluxes under ENSO conditions (Rixen et al. 2006). Although our sediment trap record did not fully cover

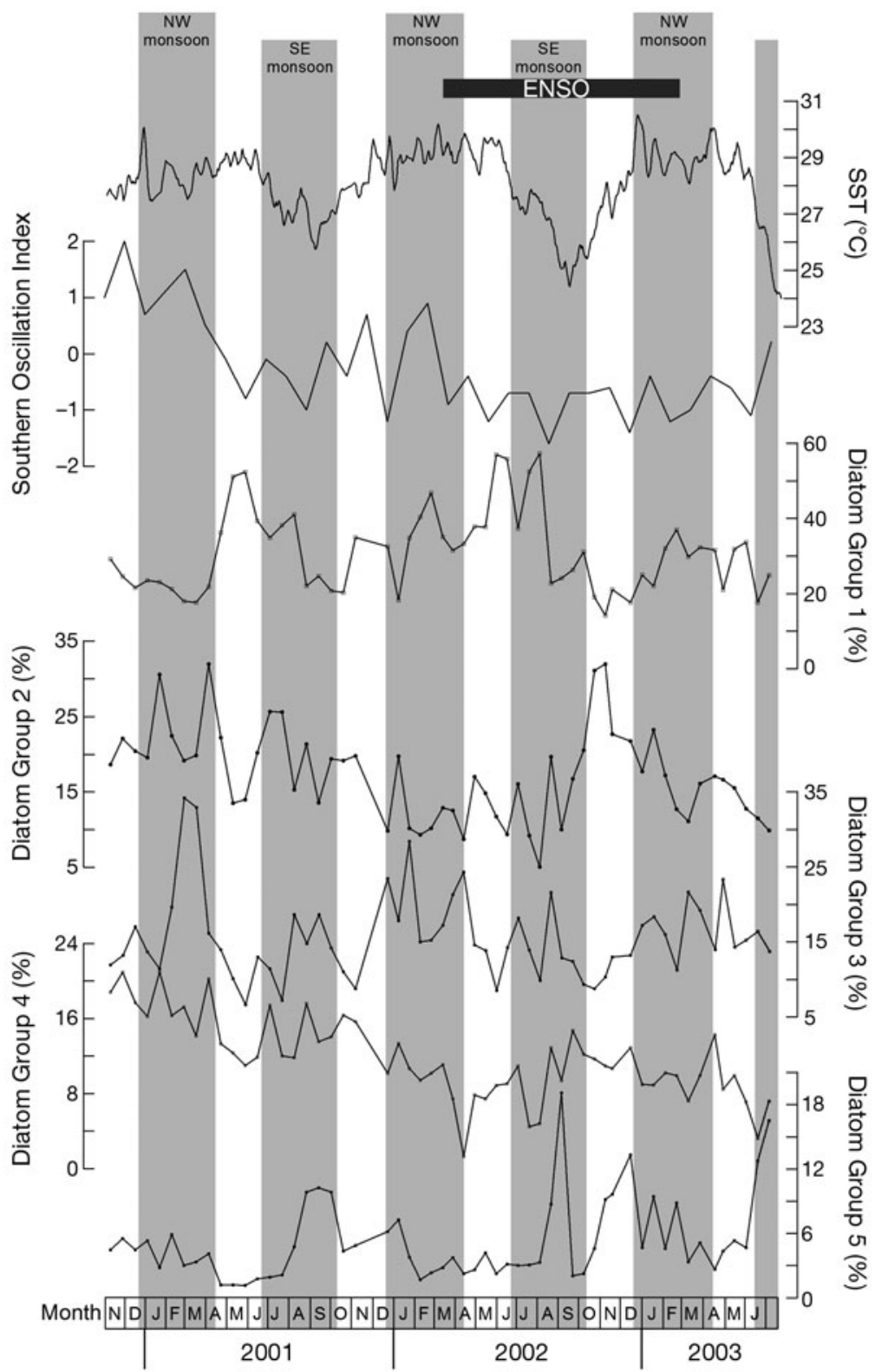

Fig. 4. Temporal changes in the relative contribution of 5 diatom groups (\%) at the mooring site JAM off southern Java in the SE tropical Indian Ocean from November 2000 through July 2003 (see Table 2 for qualitative composition of diatom groups). The Southern Oscillation Index from the NOAA Climate Prediction Center (www.cpc.ncep.noaa.gov/data/indices) and the sea surface temperature (SST, ${ }^{\circ} \mathrm{C}$ ) are also shown. Grey shading highlights the NW and SE upwelling seasons. ENSO: El Niño/Southern Oscillation the entire upwelling period during the $2003 \mathrm{SE}$ monsoon season, maxima of diatom, opal and organic carbon recorded by late June 2003, 1 mo earlier than in the 2001 and 2002 cycles, points to the vigorous onset of the upwelling season in 2003. Additional evidence for the occurrence of more intense upwelling in June/July 2003 was given by the strong decrease in SST, exceeding the lowest values recorded in previous years (Fig. 4).

Seasonal differences in the magnitude of opal and diatom maxima can be seen for the JAM site. Although the opal fluxes during the 2003 SE monsoon increased after the preceding moderate ENSO conditions, the diatom flux was higher during the SE monsoon in 2001 than in 2003 (Fig. 3). The composition of the diatom assemblage, as well as the degree of silicification and size of the valves, might have contributed to the different magnitudes of the opal and diatom maxima. While diatoms attributed to PCA Groups 2, 3 and 5 were the main contributors to the SE monsoon peak in 2001, a much more diverse assemblage occurred during the 2003 SE monsoon (Fig. 6).

Temporal changes in the species composition of the diatom community at the JAM site off Java were related to the seasonal dynamics of the main hydrographic and atmospheric conditions in the tropical SE Indian Ocean. The occurrence of resting spores of Chaetoceros spp. (Group 5), typical of high-productivity, coastal upwelling regimes of low-to-intermediate latitudes in the world's oceans (Romero et al. 2001, 2002, 2009), revealed high nutrient input during the upwelling periods associated with the SE monsoon. After the dominant La Niña conditions in 2001, a stronger riverine discharge followed during the SE upwelling season 2001 off southern Java. Since the contribution of Chaetoceros spp. resting spores increased during the late SE upwelling season in 2001 (Fig. 6), we speculate that the moderate flux of opal during the later phase of the SE monsoon in 2001 was a consequence of less-silicified valves produced in surface waters.

\section{Intermonsoon}

The transition months between monsoon seasons, April/May and October/November, showed the lowest wind speed and 
wind stress off southern Java (Susanto et al. 2006). The weakening of the wind system was coupled with the uninterrupted rise in SST (Fig. 4), the reduction in the vertical mixing and the decrease of the nutrient content in the upper water column (Susanto et al. 2001).

The diatom assemblage quickly responded to the changing atmospheric and oceanographic conditions during the intermonsoon periods off southern Java (Fig. 6). The dominance of diatom Group 1 during intermonsoons mirrored the highly stratified, nutrient-depleted surface waters and low primary productivity (chlorophyll $\mathrm{a}<0.2 \mathrm{mg} \mathrm{C} \mathrm{m}{ }^{-3} \mathrm{~h}^{-1}$; Qu et al. 2005, Susanto et al. 2006). It is well known that small Nitzschia bicapitata and $N$. interruptestriata, main contributors to Group 1, are common components of the open-ocean, nutrient-poor waters of tropical and subtropical areas of the world's oceans during periods of productivity collapse, following the shutdown of nutrient entrainment and the onset of stratification (Romero et al. 1999, 2000). Similarly, Koning et al. (2001) associated high numbers of $N$. bicapitata off Somalia with the retreating monsoonal upwelling in the western Indian Ocean.

\section{NW monsoon}

Weakened river discharge under ENSO conditions was assumed to cause the flux decrease by late 2002 during NW monsoons off southern Java (Rixen et al. 2006). This interpretation was supported by the enhanced flux of organic carbon under La Niña conditions (NW monsoon in 2000/2001), yet slightly reduced organic carbon flux during the early 2002 ENSO (NW monsoon in 2001/2002). Our longer time-series data, however, show highest opal and organic carbon fluxes during the 2002/2003 NW monsoon, following a moderate ENSO event (Fig. 4). The impact of river discharge on export fluxes off Java and Sumatra might play an important role in the spatial variation of collected fluxes. In areas where the terrestrial nutrients are not consumed and exported from the euphotic zone, the biological production is generally enhanced, while enhanced stratification in the upper water column reduces the input of nutrients into subsurface waters (Ittekkot et al. 1991). Accordingly, we have interpreted that the occurrence of high fluxes during the NW monsoon in 2002/2003 was mainly caused by the input of nutrients from subsurface waters, due to the ENSO-driven, weakened freshwater discharges, which led to stronger vertical mixing. Our assumption was supported by the increased flux of lithogenics (Fig. 2), considered to be indicative of both stronger riverine input (Hendiarti et al. 2004) and increased availability of nutrients in surface waters off southern Java (Rixen et al. 2006 and references therein).
Further support for our interpretation is given by the diatom community thriving at the JAM site. Diatoms of Group 3, mainly Thalassionema nitzschioides var. nitzschioides, represented nutrient-enriched coastal conditions associated with the occurrence of the NW monsoon season off southern Java (Fig. 6). The presence of $T$. nitzschioides var. nitzschioides indicated

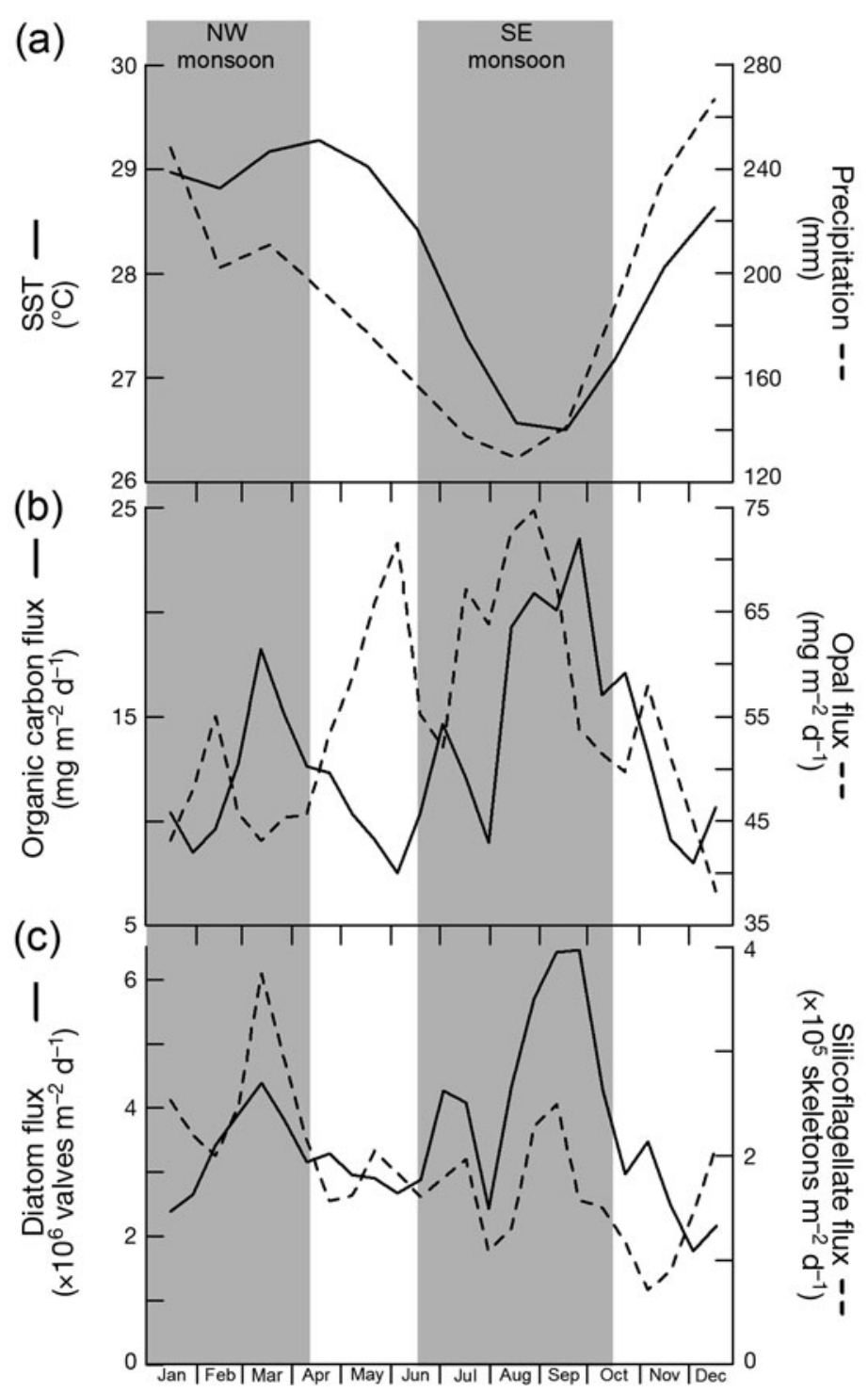

Fig. 5. (a) Monthly mean SST selected for the JAM site and the Indonesian continental precipitation rates derived from the German Weather Service. The global and $1 \times 1^{\circ}$ gridded SST and the precipitation rates were averaged for the areas 108 to $109^{\circ} \mathrm{E}$ and 8 to $9^{\circ} \mathrm{S}$, as well as for 95 to $135^{\circ} \mathrm{E}$ and $10^{\circ} \mathrm{S}$ to $7^{\circ} \mathrm{N}$. (b) Bi-weekly organic carbon and opal fluxes and (c) bi-weekly diatom and silicoflagellate fluxes averaged for the sampling period between November 2000 and July 2003 at the JAM site off southern Java. Bi-weekly values were calculated by lineally interpolating daily fluxes on a $14 \mathrm{~d}$ basis for the entire JAM trap experiment. Grey shading indicates the NW and SE monsoon periods 


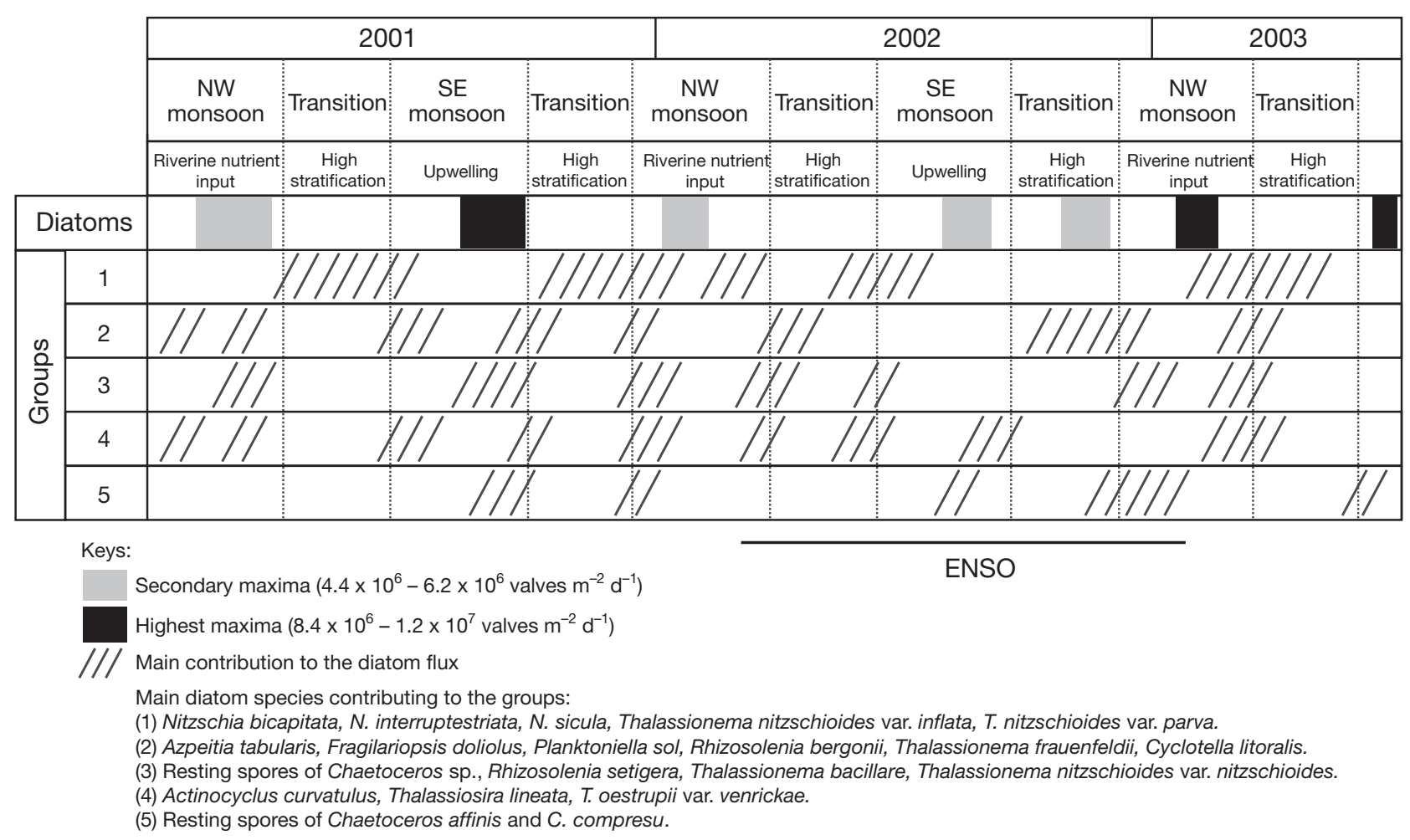

Fig. 6. Schematic of the temporal distribution of monsoon seasons and transition periods of diatom maxima and diatom species or groups of species at the pelagic JAM site in the tropical SE Indian Ocean between November 2000 and July 2003. Black shading: highest diatom maxima; grey shading: moderate diatom maxima; diagonal lines: periods of higher contribution for each diatom group. ENSO: El Niño/SouthernOscillation

increased nutrient supply from subsurface waters, in combination with some freshwater fluvial input (Romero et al. 2002). Similarly, Koning et al. (2001) observed that $T$. nitzschioides dominated the diatom assemblage during periods of more intense upwelling and low SST off Somalia.

A comparison of available diatom fluxes for the tropical Indian Ocean shows some differences on an annual basis. Although this comparison was mainly based on different sampling periods (2001 to 2003, eastern basin, [present study], vs. 1992 to 1993, western basin [Koning et al. 2001]), the total yearly diatom fluxes in open-ocean areas off southern Java and in the Somali Basin were on the same order of magnitude $\left(10^{9}\right.$ valves $\left.\mathrm{m}^{-2} \mathrm{~d}^{-1}\right)$, while diatom fluxes measured over the Somalian slope were 1 order of magnitude higher (Koning et al. 2001). This difference might reflect (1) higher values of primary production of the surface waters (Antoine et al. 1996) and silicate content in the subsurface waters off Somalia (Ragueneau et al. 2000), or (2) year-to-year differences due to different sampling periods.

During the moderate 2002/2003 ENSO, the qualitative composition of the diatom assemblage revealed only moderate changes off southern Java. Probably as a response to ENSO occurrence and the associated intensification of the upwelling, the contribution of diatom Group 5 increased by the late SE monsoon season in 2002 (Fig. 6). Immediately following this, an enhanced contribution of Group 2 diatoms in the SE to NW monsoon transition reflected similar hydrographic conditions to those already described for diatom Group 1: waters of low-to-moderate nutrient content and diatoms occurring most abundantly when stratification is high. The low relative contribution of diatom Group 1 points to more productive surface waters under the preceding La Niña conditions than during transition periods.

The response to ENSO events shown by the trapped diatom assemblage differed among various regions of the world's oceans. Although total diatom fluxes in the subarctic Pacific Ocean decreased significantly in response to the 1982/1983 ENSO, the composition of the diatom flora revealed only minor changes (Takahashi 1987). Similarly, the upwelling-associated resting spores of Chaetoceros spp. dominated the diatom community in coastal waters off northern Chile under both ENSO and La Niña conditions (Romero et al. 2001). On the contrary, significant changes in the qualitative composition of the diatom community in other 
low-latitude coastal systems were related to the occurrence of ENSO. An increase in the relative contribution of eastern tropical Pacific diatoms and the simultaneous decrease of coastal-upwelling diatoms in the Santa Barbara Basin in 1997/1998 were associated with warm-water incursions into the near-shore area off California and decreased upwelling intensity due to the occurrence of ENSO (Lange et al. 1997). In the Cariaco Basin off Venezuela, the composition of the diatom assemblage showed a major shift during the boreal winter following the strong 1997/1998 ENSO: the highly diverse diatom assemblage during ENSO years comprised a mixture of pelagic and coastal planktonic diatoms, while only coastal diatoms dominated during La Niña years in the same region (Romero et al. 2009). However, a comprehensive understanding of the ENSO-driven forcing on the interannual variability of diatom fluxes in the tropical Indian Ocean requires further investigation, which should be complemented by longer term data sets to establish more clearly its role in the development of the diatom community response and the cascade to the rest of the food web.

\section{CONCLUSIONS}

A central objective of our work was to determine whether and when the production and export of particulates, diatoms and silicoflagellates off southern Java occurs. To answer this question we followed the yearround flux of particulates and the quantitative and qualitative changes of the trapped diatom assemblage for ca. 2.5 yr. Our main observations are summarized as follows:

(1) Fluxes of diatoms, opal and organic carbon were highest during the NW and SE monsoon seasons off southern Java. During the SE monsoon season, the flux dynamics were driven by the occurrence of upwelling, whereas riverine nutrient input seems to be the main mechanism behind the increase of fluxes during the NW monsoon season.

(2) The occurrence of ENSO has a moderate effect on the production and export of diatoms. The ENSOinduced reduction of riverine nutrient discharge increased the fluxes during both monsoon seasons by weakening the stratification in the upper water column.

(3) Diatoms were the most important contributors to opal production and export measured off southern Java. The highly diverse diatom community at the JAM site was a mixture of representatives from pelagic conditions (mainly Nitzschia bicapitata, N. interruptestriata and N. sicula), high productivity, coastal upwelling (resting spores of Chaetoceros spp., Thalassionema nitzschioides var. nitzschioides and Cyclotella litoralis) and coastal planktonic diatoms (Actinocyclus curvatulus and Thalassiosira oestrupii var. venrickae). The dominance of pelagic, tropical/subtropical diatoms with secondary contributions by upwelling-associated and coastal planktonic diatoms reflected the influence of both offshore and coastal waters, with considerable hydrographic variability over short time intervals.

(4) A moderate shift in the composition of the diatom community occurred during the 2002/2003 ENSO event off southern Java. Probably as a response to ENSO occurrence and the associated intensification of upwelling, the contribution of coastal upwelling diatoms increased by late 2002 .

Acknowledgements. This research was supported, in part, by grants to O.E.R. by the German Research Foundation and the Spanish Council for Scientific Research. The present study was carried out within the framework of the bilateral Indonesian-German research program SPICE II (Science for the Protection of Indonesian Coastal Marine Ecosystems) sponsored by the German Federal Ministry of Education and Research (Grant No. 03F0463A), the Indonesian Ministry of Marine Affairs and Fisheries (DKP) and the Ministry for Research and Technology (RISTEK). O.E.R. thanks E. Kwoll for her laboratory work. Two anonymous reviewers are gratefully acknowledged for their contributions in correcting and improving this work. The data are available from the PANGAEA database (www.pangaea.de).

\section{LITERATURE CITED}

Antoine D, André JM, Morel A (1996) Oceanic primary production. 2. Estimation at a global scale from satellite (Coastal Color Zonal Scanner) chlorophyll. Global Biogeochem Cycles 10:57-69

Godfrey JS (1996) The effect of the Indonesian throughflow on ocean circulation and heat exchange with the atmosphere: a review. J Geophys Res 101:12217-12238

Gordon AL (2005) Oceanography of the Indonesian seas and their throughflow. Oceanography 18:14-27

Gordon AL, Fine RA (1996) Pathways of water between the Pacific and Indian oceans in the Indonesian seas. Nature 379:146-149

> Gordon AL, Weiss RF, Smethie WM, Warner MJ (1992) Thermocline and intermediate water communication between the South Atlantic and Indian Oceans. J Geophys Res 97:7223-7240

> Hendiarti N, Siegel H, Ohde T (2004) Investigation of different coastal processes in Indonesian water using SeaWiFS data. Deep Sea Res II Top Stud Oceanogr 51:85-97

> Hirst AC, Godfrey JS (1993) The role of Indonesian throughflow in a global ocean GCM. J Phys Oceanogr 23: 1057-1086

Ittekkot V, Nair RR, Honjo S, Ramaswami V, Bartsch M, Manganini S, Desai BN (1991) Enhanced particle fluxes in Bay of Bengal induced by injection of fresh water. Nature 351: 385-387

> Koning E, van Iperen JM, van Raaphorst W, Helder W, Brummer GJA, van Weering TCE (2001) Selective preservation of upwelling-indicating diatoms in sediments off Somalia, NW Indian Ocean. Deep Sea Res I Oceanogr Res Pap 48: 2473-2495 
Lange CB, Weinheimer AL, Reid FHM, Thunell RC (1997) Sedimentation patterns of diatoms, radiolarians, and silicoflagellates in Santa Barbara Basin, California. Calif Coop Ocean Fish Invest Rep 38:161-170

Moore TS II, Marra J, Alkatiri A (2003) Response of the Banda Sea to the southeast monsoon. Mar Ecol Prog Ser 261: 41-49

Mortlock RA, Froelich PN (1989) A simple method for the rapid determination of biogenic opal in pelagic marine sediments. Deep-Sea Res 36:1415-1426

Neale RB, Slingo JM (2003) The Maritime Continent and its role in the global climate: a GCM study. J Clim 16: 834-848

Qu T, Du Y, Strachan J, Meyers G, Slingo J (2005) Sea surface temperature and its variability in the Indonesian Region. Oceanography 18:50-51

Ragueneau O, Tréguer P, Leynart A, Anderson RF and others (2000) A review of the Si cycle in the modern ocean: recent progress and missing gaps in the application of biogenic opal as a paleoproductivity proxy. Global Planet Change 26:317-365

Rixen T, Ittekkot V, Herunadi B, Wetzel P, Maier-Reimer E, Gaye-Haake B (2006) ENSO-driven carbon seesaw in the Indo-Pacific. Geophys Res Lett 33:L07606

Romero OE, Lange CB, Fischer G, Treppke UF, Wefer G (1999) Variability in export production documented by downward fluxes and species composition of marine planktonic diatoms: observations from the tropical and equatorial Atlantic. In: Fischer G, Wefer G (eds) The use of proxies in paleoceanography, examples from the South Atlantic. Springer-Verlag, Heidelberg, p 365-392

Romero OE, Fischer G, Lange CB, Wefer G (2000) Siliceous phytoplankton of the western equatorial Atlantic: sediment traps and surface sediments. Deep Sea Res II Top Stud Oceanogr 47:1939-1959

Romero OE, Hebbeln D, Wefer G (2001) Temporal and spatial distribution in export production in the SE Pacific Ocean: evidence from siliceous plankton fluxes and surface sediment assemblages. Deep Sea Res I Oceanogr Res Pap 48: 2673-2697

Romero OE, Lange CB, Wefer G (2002) Interannual variability (1988-1991) of siliceous phytoplankton fluxes off northwest Africa. J Plankton Res 24:1035-1046

Romero OE, Thunell RC, Astor Y, Varela R (2009) Seasonal and interannual dynamics in diatom production in the Cariaco Basin, Venezuela. Deep Sea Res I 56:571-581

Saji NH, Goswami BN, Vinayachandran PN, Yamagata T (1999) A dipole mode in the tropical Indian Ocean. Nature 401:360-363

Sancetta C, Calvert SE (1988) The annual cycle of sedimentation in Saanich Inlet, British Columbia: implications for the interpretation of diatom fossil assemblages. Deep-Sea Res 35:71-90

Simonsen R (1974) The diatom plankton of the Indian Ocean Expedition of RV Meteor 1964-1965. Meteor Forsch ergeb Reihe D Biol 19:1-66

Susanto RD, Gordon AL, Zheng Q (2001) Upwelling along the coasts of Java and Sumatra and its relation to ENSO. Geophys Res Lett 28:1599-1602

Susanto RD, Moore TS II, Marra J (2006) Ocean color variability in the Indonesian Seas during the SeaWiFS era. Geochem Geophys Geosyst 7:Q05021

Takahashi K (1987) Response of subarctic Pacific diatom fluxes to the 1982-1983 El Niño disturbance. J Geophys Res 92:14387-14392

Tomczak M, Godfrey JS (1994) Hydrology of the Indian Ocean. In: Tomczak M, Godfrey JS (eds) Regional oceanography, an introduction. Pergamon Press, Oxford, p 221-236

Webster PJ, Moore AM, Loschnigg JP, Leben RR (1999) Coupled ocean-atmosphere dynamics in the Indian Ocean during 1997-98. Nature 401:356-360

Appendix 1. The list presents all the species, varieties or forms of diatoms (Bacillariophyceae) found in JAM sediment trap samples from November 2000 through to July 2003. Each species is followed by the author's name and year of description. In a few cases we were unable to identify the taxon to the species level. If this taxon was found repeatedly the generic name was used, followed by the abbreviation 'sp.'. RS: resting spore

Actinocyclus curvatulus Janisch, 1874

A. elongatus Grunow, 1881

A. octonarius Ehrenberg, 1838

A. subtilis (Gregory) Ralfs, 1861

Actinoptychus senarius (Ehrenberg) Ehrenberg, 1838

A. vulgaris Schuman, 1867

Adoneis pacifica G. W. Andrews \& P. Rivera, 1987

Alveus marinus (Grunow) Kaczmarska \& G. Fryxell, 1996

Amphora decussata Grunow, 1877

Amphora sp.

Asterolampra marylandica Ehrenberg, 1844

Asteromphalus arachne Brébisson, 1857

A. cleveanus Grunow, 1874

A. flabellatus (Brébisson) Greville, 1859

A. heptactis (Brébisson) Ralfs, 1861

A. sarcophagus Wallich, 1860

A shadboltianus (Greville) Ralfs, 1860

Azpeitia africana (Janisch ex Schmidt) G. Fryxell \& T. P.

Watkins, 1986

A. barronii G. Fryxell \& T. P. Watkins, 1986
A. neocrenulata (Van Landingham) G. Fryxell \& T. P. Watkins, 1986

A. nodulifera (A. Schmidt) G. Fryxell \& T. P. Watkins, 1986

A. tabularis (Grunow) G. Fryxell \& T. P. Watkins, 1986

Bacteriastrum elongatum Cleve, 1897

B. furcatum Shadbolt, 1854

Biddulphia alternans (J. W. Bailey) Van Heurck, 1885

Campylodiscus clypeus (Ehrenberg) Kützing, 1844

Campyloneis sp.

Catenula pelagica Mereschkowsky, 1903

Chaetoceros affinis Lauder, 1864

C. bacteriastroides Karsten, 1907

C. concavicornis Manguin, 1917

C. decipiens Cleve, 1873

C. dydimus Ehrenberg, 1845

C. lorenzianus Grunow, 1863

C. messanensis Castracane, 1875

C. pseudocurvisetus Manguin, 1910

C. radicans Schuett, 1895

C. affinis Lauder, 1864 RS 
Appendix 1 (continued)

C. cinctus Gran, 1897 RS

C. compressus Lauder, 1864 RS

C. constrictus Gran, 1867 RS

C. coronatus Gran, 1897 RS

C. debilis Cleve RS

C. diadema (Ehrenberg) Gran, 1897 RS

C. dydimus Ehrenberg, 1845 RS

C. pseudocurvisetus Manguin, 1910 RS

C. radicans Schütt, $1895 \mathrm{RS}$

C. vanheurckii Gran, 1900 RS

Chaetoceros spp. RS

Cocconeis dirupta Gregory, 1857

C. disculus (Schumann) Cleve, 1895

C. pelta Schmidt, 1864

C. pseudomarginata Gregory, 1857

C. stauroneiformis (Rabenhorst) Okuno, 1957

Corethron criophilum Castracane, 1886

Coscinodiscus argus Ehrenberg, 1839

C. centralis Ehrenberg, 1839

C. concinnus Wm. Smith, 1856

C. reniformis Castracane, 1886

Cyclotella litoralis Lange \& Syvertsen, 1989

Cymatopleura solea (Brébisson \& Godey) Wm. Smith, 1851

Delphineis karstenii (Boden) Fryxell, 1978

D. surirella (Ehrenberg) Andrews, 1981

Detonula pumila (Castracane) Gran, 1900

Diplomenora sp.

Diploneis bombus Ehrenberg, 1844

D. didyma (Ehrenberg) Cleve, 1880

D. papula var. constricta Hustedt, 1927

Ditylum brightwellii (West) Grunow, 1880

Entomoneis alata (Ehrenberg) Kützing, 1884

Fallacia nyella (Hustedt ex Simonsen) D. G. Mann, 1990

Fragilariopsis doliolus (Wallich) Medlin \& Sims, 1996

Gosleriella tropica Schütt, 1892

Grammatophora marina (Lyngbye) Kützing, 1884

Guinardia cylindrus (Cleve) Hasle, 1996

Haslea gigantea (Hustedt) Simonsen, 1974

H. hyalinissima Simonsen, 1974

Hemiaulus hauckii Grunow, 1880

H. membranaceus Cleve, 1873

Hemidiscus cuneiformis Wallich, 1860

Hyalodiscus stelliger J. W. Bailey, 1854

Leptocylindrus mediterraneus (H. Peragallo) Hasle, 1975

Licmophora sp.

Lioloma elongatum (Grunow) Hasle, 1996

Mastogloia sp.

Navicula distans Wm. Smith, 1853

Navicula sp.

Neodelphineis indica (F. J. R. Taylor) Hasle, 1993

Nitzschia bicapitata Cleve, 1901

N. braarudii Hasle, 1960

N. capuluspalae Simonsen, 1974

N. dietrichii Simonsen, 1974

N. interruptestriata (Heiden) Simonsen, 1974

N. kolaczekii Grunow, 1867

N. longicollum Halse, 1960

N. sicula (Castracane) Hustedt, 1958

$N$. sicula aff. $N$. cf. sicula

Nitzschia spp.

Odontella aurita (Lyngbie) Agardh, 1832

O. longicruris (Greville) Hoban, 1983

O. mobiliensis Bailey, 1845
Opephora sp.

Paralia sulcata (Ehrenberg) Cleve, 1873

Planktoniella sol (Wallich) Schütt, 1860

Pleurosigma directum Grunow, 1880

P. planktonicum Simonsen, 1974

Porosira denticulata Simonsen, 1974

Proboscia alata (Brightwell) Sundström, 1986

P. alata f. indica (Peragallo) Sundström, 1986

Psammodiscus nitidus (Gregory) Round \& D. G. Mann, 1980

Psammodyction panduriformis (Gregor) D. G. Mann, 1990

Pseudo-nitzschia inflatula var. capitata Simonsen, 1974

P. pungens (Grunow ex Cleve) Hasle, 1965

$P$. pungiformis (Hasle) Hasle, 1971

P. subfraudulenta Hasle, 1965

Pseudosolenia calvar-avis (Schultze) Sundström, 1986

Pseudotriceratium punctatum (Wallich) Simonsen, 1974

Rhizosolenia acicularis Sundström, 1986

R. acuminata (H. Peragallo) H. Peragallo, 1892

$R$. bergonii H. Peragallo, 1892

$R$. borealis Sundström, 1986

$R$. imbricata Brightwell, 1858

R. robusta Norman, 1861

R. setigera Brightwell, 1858

$R$. styliformis Brightwell, 1858

Roperia tesselata (Roper) Grunow, 1880

Skeletonema costatum (Greville) Cleve, 1873

Surirella sp.

Tabullaria sp.

Thalassionema bacillare (Heiden) Kolbe, 1955

Thalassionema aff. $T$. cf. bacillare 1

Thalassionema aff. T. cf. bacillare 2

T. frauenfeldii (Grunow) Hallegraeff, 1986

T. nitzschioides var. nitzschioides (Grunow) Van Heurck, 1880

T. nitzschioides var. capitulata (Castracane) Moreno-Ruiz, 1996

T. nitzschioides var. inflata Kolbe, 1928

T. nitzschiodes var. parva (Heiden) Moreno-Ruiz, 1996

T. pseudonitzschioides (Schuette \& Schrader) Hasle, 1996

Thalassiora angulata (Gregory) Hasle, 1978

T. bioculata (Grunow) Ostenfeld, 1908

T. conferta Hasle, 1977

T. delicatula Ostenfeld, 1908

T. diporocyclus Hasle, 1972

T. eccentrica (Ehrenberg) Cleve, 1904

T. elsayedii G. Fryxell, 1975

T. endoseriata Hasle \& G. Fryxell, 1977

T. ferelineata Hasle \& G. Fryxell, 1977

T. leptopus (Grunow) Hasle \& G. Fryxell, 1977

T. lineata Josué, 1968

T. nanolineata (Mann) G. Fryxell \& Hasle, 1977

T. oestrupii var. oestrupii (Ostenfeld) Hasle, 1972

T. oestrupii var. venrickae G. Fryxell \& Hasle, 1972

T. partheneia Schrader, 1972

T. plicata (Grunow) Schrader, 1974

T. poroseriata (Ramsfjell) Hasle, 1972

T. punctigera (Castracane) Hasle, 1983

T. sacketii f. sacketii G. Fryxell, 1977

T. sacketii f. plana G. Fryxell, 1977

T. subtilis (Ostenfeld) Gran, 1900

T. symmetrica G. Fryxell \& Hasle, 1972

Thalassiosira sp. 
Appendix 1 (continued)

Thalassiothrix spathulata Hasle, 1999

Toxarium sp.

Trachyneis aspera Cleve, 1894

Trigonium sp.

Freshwater diatoms

Achnanthes delicatula (Kützing) Grunow, 1880

Aulacoseira granulata (Ehrenberg) Ralfs in Pritchard, 1861

Cyclotella meneghiniana Kützing, 1884

Cymbella sp.
Epithemia sp.

Eunotia sp.

Gomphonema sp.

Hantzschia amphyoxis (Ehrenberg) Grunow, 1880

Luticola mutica (Kütz.) D. G. Mann, 1990

Navicula cryptotenella Lange-Bertalot, 1985

Pinnularia sp.

Rhopalodia sp.

Sellaphora pupula Kützing, 1844

Editorial responsibility: Katherine Richardson,

Copenhagen, Denmark
Submitted: December 17, 2008; Accepted: March 18, 2009

Proofs received from author(s): May 13, 2009 